WellBeing International

WBI Studies Repository

6-2004

\title{
Ideology Masquerading as Science: The Case of Endocrine Disrupter Screening Programmes
}

Troy Seidle

People for the Ethical Treatment of Animals

Follow this and additional works at: https://www.wellbeingintlstudiesrepository.org/acwp_arte

Part of the Bioethics and Medical Ethics Commons, Laboratory and Basic Science Research Commons, and the Research Methods in Life Sciences Commons

\section{Recommended Citation}

Seidle, T. (2004). Ideology masquerading as science: the case of endocrine disrupter screening programmes. ATLA-NOTTINGHAM-, 32, 669-672.

This material is brought to you for free and open access by WellBeing International. It has been accepted for inclusion by an authorized administrator of the WBI Studies Repository. For more information, please contact wbisr-info@wellbeingintl.org.

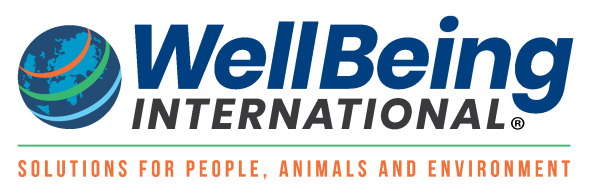




\title{
Ideology Masquerading as Science: The Case of Endocrine Disrupter Screening Programmes
}

\author{
Troy Seidle \\ People for the Ethical Treatment of Animals, 501 Front Street, Norfolk, VA 23510, USA \\ E-mail: troys@peta.org
}

\begin{abstract}
Summary - The global move to develop novel testing methods and strategies to identify suspected endocrine disrupting chemicals offers a unique opportunity to move away from traditional animal testing paradigms in this new area of regulatory concern. Regrettably, the programmes under development, both in the USA and internationally through the OECD, have thus far failed to consider in vitro and other nonanimal test methods as more than "pre-screening" or "priority-setting" tools in a larger, animal-based testing strategy. Validation efforts to date have focused almost exclusively on the modification of existing animal tests to detect "endocrine effects", with no demonstrable effort to promote international coordination or support for the development and validation of relevant non-animal test systems. The current orientation in these programmes reflects ideological, rather than scientific, imperatives, and undermines the commitments of both the US government and the OECD with respect to the Three Rs and the minimisation of animal testing.
\end{abstract}

Key words: endocrine disrupter testing, non-animal test methods.

\section{Introduction}

The term "endocrine disrupter" entered the public lexicon in 1996, with the publication of the book, Our Stolen Future: Are We Threatening Our Fertility, Intelligence and Survival? - A Scientific Detective Story (1). The book, co-authored by environmental activist, and later WWF senior scientist, Theo Colborn, sought to implicate synthetic chemicals as the root of everything from reproductive anomalies in wildlife to neurodevelopmental deficits in human children.

Although Our Stolen Future received considerable hype in the mainstream media, scientific publications were less enthusiastic about the book or the scientific rigor of its authors. For example, a Scientific American editorial (2) concluded: "The book is not scientific. . . The authors present a very selective segment of the data that have been gathered about chemicals that might affect hormonal functions. They carefully avoid evidence and interpretations that are not in accord with their thinking". Similarly, a review published in the journal, Science (3), noted, “. . . the authors' lack of discrimination between anecdotal reports and meticulous scientific studies. One paragraph describes a carefully crafted study, the next indulges in wild speculation. . . . This lack of selectivity diminishes the impact of the book because it raises serious questions about the scientific judgment of the authors".

Just when the media hype surrounding Our Stolen Future began to fade, investigators at Tulane University published a study reporting that combinations of polychlorinated biphenols (PCBs) and pesticides were up to 1000 times more potent as endocrine disruptors than the individual chemicals alone (4). According to former US Environmental Protection Agency (EPA) administrator, Carol Browner (5): "The new study is the strongest evidence to date that combinations of oestrogenic chemicals may be potent enough to significantly increase the risk of breast cancer, prostate cancer, birth defects and other major health concerns". Similar views were expressed by then EPA Assistant Administrator for Prevention, Pesticides and Toxic Substances, Lynn Goldman, who described the Tulane study (6) as, "the best case of synergy between chemicals at low doses that I have ever seen", and further, that "I just can't remember a time where I've seen data so persuasive. . . . The results are very clean-looking" (see 5).

\section{Discussion}

The Tulane study received a great deal of publicity, which played a considerable role in driving the US Congress to pass the Food Quality Protection Act of 1996 (7), which requires the EPA to "develop a screening programme ... to determine whether certain substances may have an effect in humans that is similar to an effect produced by a naturally occurring oestrogen, or such other endocrine effect as the Administrator may designate". However, a mere six months after its publication, the Tulane study began to unravel. Scientists from around the world began to report that they could not reproduce the study's results (8, 9). By August 1997, the study's lead author had retracted the study from publica- 
tion (10). Subsequently, the US Office of Research Integrity (ORI) concluded that the study's authors, "committed scientific misconduct by intentionally falsifying the research results published in the journal Science and by providing falsified and fabricated materials to investigating officials" (11). ORI also found that, "there is no original data or other corroborating evidence to support the research results and conclusions reported in the Science paper as a whole". The penalty imposed was a 5-year ban from receiving US federal grants.

Quite apart from the controversy surrounding the Tulane study, a number of eminent scientists began to question the relevance and timeliness of a large-scale programme to test chemicals for suspected "endocrine disrupting" effects. The US National Research Council report, Hormonally Active Agents in the Environment (12), noted: "There are important differences among species and between adult and developing organisms in responses to endocrine disrupters. These differences could have important implications when assessing toxicity studies or extrapolating data from one species to another". Similarly, an editorial by Ashby \& Elliott (13) in the journal Regulatory Toxicology and Pharmacology, documented a litany of examples of the difficulties encountered in attempting to reproduce observations reported in studies of endocrine disruption, noting: "In some cases, effects will not reproduce because they were not real". Even members of the environmental community have questioned the foundation of the Endocrine Disruptor Screening Program (EDSP; 14), noting that endocrine disruption is becoming the "industry endpoint of choice", because such a classification will place a chemical into a "bottomless pit of study" in a "regulatory safety zone". Perhaps most telling, however, are comments made by Dr Ernest McConnell, then chair of the EPA's Scientific Advisory Panel/Science Advisory Board joint subcommittee on endocrine disrupters, that "... there was an undercurrent through the whole discussion that the EPA programme was ahead of the science. . . . This may not be the best use of our nation's resources".

Remarkably, the retraction of the Tulane study and the sage words of caution from respected scientific authorities were barely a bump in the road to the mass testing of chemicals for suspected "endocrine disrupting" effects, which suggests that politics - as opposed to science - is the major driver behind endocrine disrupter testing programmes.

\section{Questionable guidance}

The EDSP in the USA is being structured according to the recommendations of the EPA's former Endocrine Disrupter Screening and Testing
Advisory Committee (EDSTAC), which included representation from all major stakeholder groups, with the exception of the animal protection community (15). Perhaps not surprisingly, the Three $\mathrm{Rs}_{\mathrm{S}}$ of reduction, refinement and replacement were also not considered or reflected in EDSTAC's report and recommendations to the EPA (16). In fact, many of EDSTAC's "screening criteria" (17) are antithetical to the Three Rs, including the promotion of "redundancy among endpoints across assays", and the relegation of in vitro methods to mere "priority setting" status by establishing, a priori, that "the results of in vivo assays should be given greater weight than similar results in vitro". EDSTAC also failed to appreciate the importance of proper validation, by suggesting that in vivo methods are "generally well accepted in toxicity testing", which erroneously equates a history of use with validation (18).

Activity in the USA is also being mirrored internationally. In 1996, the OECD established a Task Force on Endocrine Disrupter Testing and Assessment (EDTA), with representation from both national governments and non-governmental entities. From the EDTA emerged two Validation Management Groups (VMGs), each with a mandate to oversee the development and validation of exclusively in vivo tests, for mammalian and ecotoxicological effects, respectively. It was only in June of 2002 that in vitro and other non-animal approaches began to be given serious consideration or prominence in the OECD's proposed "toolbox" of screening and testing methods. This modest, but important, shift culminated with a proposal to establish a third VMG specific to non-animal screening and testing methods.

Although there now appears to be some visible movement toward a more holistic application of the Three $\mathrm{Rs}_{\mathrm{s}}$ - including Japan's leadership in the development of high-throughput screening systems (J. Kanno, personal communication), the EPA's work to develop a cell-line model for steroidogenesis/aromatase inhibition (19), an in vitro amphibian gene array for ecotoxicity screening (G. Timm, personal communication, 12.5.01), and recent movement toward a "Technology Challenge" funding programme (20) - there are still numerous areas in which the Three Rs are being applied inadequately, if at all.

\section{Failure to adequately apply the Three Rs}

There is currently an unconscionable amount of redundancy in the assays being developed in both the USA and internationally. For example:

1. The EPA has proposed to develop and validate several separate iterations of a pubertal assay (21). 
2. Proposed testing frameworks, both in the USA and internationally, include five redundant and highly animal-intensive chronic/multi-generational reproduction studies in multiple taxonomic groups $(18,22)$.

3. There are several examples where a multiplicity of assays is being developed for the same endpoint. These include the amphibian metamorphosis and pubertal assays to assess thyroid disruption, the uterotrophic and pubertal female assays for oestrogen agonism/antagonism, and the Hershberger and pubertal male assays for androgen agonism/antagonism (23).

Had the EPA stuck to the letter of the law, i.e. "to determine whether certain substances may have an effect in humans that is similar to an effect produced by a naturally occurring oestrogen" (7), animal testing could be vastly reduced. For example, screening only for human health effects, as was the intent of the Food Quality Protection Act, would preclude the need to examine the various ecotoxicity endpoints. This would eliminate the amphibian metamorphosis and fish screening assays (vitellogenin induction and gonadal histopathology) from the EPA's proposed Tier 1, and, more importantly, from a reduction perspective, four of the five animalintensive chronic/multi-generational reproduction studies from Tier 2 (22). Compelling ethical and practical considerations favour such an approach. The final report of the EPA's joint Scientific Advisory Panel and Science Advisory Board (SAP/SAB) subcommittee on endocrine disrupters (24) states the matter very clearly: "We are concerned about the large number of animals that would be needed by the EDSTAC programme. The agency has an obligation to conserve all resources in developing new testing protocols, and the use of animals in such tests poses both ethical and practical problems. The subcommittee recommends . . . minimising the number of animals needed for testing". From a strictly pragmatic perspective, there are very few examples of substances being subject to more-stringent regulation on the basis of ecological effects in the absence of adverse human health effects (A. Rispin, personal communication). It is therefore not at all clear that the results of wildlifepoisoning studies will have any appreciable impact on the manner in which chemicals are regulated, or otherwise the manner in which regulatory agencies fulfil their mandate to protect wildlife and the environment.

At this point, it should go without saying that regulatory agencies could do much more from a reduction perspective. Both individual toxicologists and companies like Proctor \& Gamble have proposed that mechanistic/Tier 1 screening can and should be carried out by using strictly in vitro methods $(25,26)$. To date, this option has been given inadequate consideration, both in the USA and internationally.

Protocol refinement is also being overlooked, as evidenced by the overemphasis on using mature animals in the validation of the uterotrophic and Hershberger assays (27) — which results in animals being subjected to unnecessary and invasive surgical sterilisation.

Promising replacement options should be given greater attention. Examples include the study of vitellogenin induction in vitro rather than in fish (28-30), the use of in vitro metabolism and biokinetic studies to enhance receptor-binding assays (31), which could potentially serve as a replacement for the uterotrophic and Hershberger assays, and the assessment of adverse effects on the thyroid through in vitro studies of thyroid biochemistry and cell morphology (32-34).

\section{Conclusions}

Failure by regulatory agencies to fully embrace and apply the Three Rs at every stage in their chemical testing and assessment strategies will result in a magnitude of animal suffering and death that is as unconscionable as it is avoidable. The mass animal testing frameworks proposed to date did not fall from the sky on stone tablets - they merely reflect the perspective of a select group of stakeholders at one point in time. They should not be adhered to in a rigid and inflexible manner, and must continually evolve to reflect both scientific and ethical advancements.

The animal protection community is committed to working constructively with regulatory agencies and other stakeholders to further this end. However, it will take much more than reiterating one's commitment to animal welfare and the Three $\mathrm{Rs}$ to get the job done. The time for talk is over. What is needed now, is action.

\section{References}

1. Colborn, T., Dumanoski, D. \& Peterson Myers, J. (1996). Our Stolen Future: Are We Threatening Our Fertility, Intelligence and Survival? - A Scientific Detective Story. New York, NY, USA: Dutton.

2. Kamrin, M.A. (1996). Editorial Review of Our Stolen Future. Scientific American 275, 178-179.

3. Hirshfield, A.N. (1996). Book Review of Our Stolen Future. Science, New York 272, 1444-1445.

4. Arnold, S.F., Klotz, D.M., Collins, B.M., Vonier, P.M., Guillette, L.J. Jr \& McLachlan, J.A. (1996). Synergistic activation of estrogen receptor with combinations of environmental chemicals. Science, New York 272, 1489-1492.

5. Browner, C., quoted in "EPA programme based on false information" (S. Milloy). Fox News On-line, 9 November 2001. Web site http://www.foxnews.com/ story/0,2933,38366,00.html (Accessed 08.12.02).

6. Goldman, L., quoted in "Scientist withdraws study on 'synergistic' potency of multiple oestrogenic 
chemicals". Bureau of National Affairs - Daily Environment Report 146, 30 July 1997. Web site http://www.bna.com (Accessed 08.12.02).

7. Food Quality Protection Act, Public Law 104-170, August 3, 1996.

8. Kaiser, J. (1997). Synergy paper questioned at toxicology meeting. Science, New York 275, 1879.

9. Ashby, J., Lefevre, P.A., Odum, J., Harris, C.A., Routledge, E.J. \& Sumpter, J.P. (1997). Synergy between synthetic oestrogens? Nature, London $\mathbf{3 8 5}$, 494.

10. Arnold, S.F. (1997). Science, New York 277, 462.

11. US Office of Research Integrity (2001). Notice of final action. Federal Register 66, 52137. Web site http://ori.dhhs.gov/html/misconduct/arnold.asp. Washington, DC, USA: US Department of Health and Human Services (Accessed 08.12.02).

12. US National Research Council (1999). Hormonally Active Agents in the Environment, 430pp. Washington, DC, USA: National Academy Press.

13. Ashby, J. \& Elliott, B.M. (1997). Reproducibility of endocrine disruption data. Regulatory Toxicology and Pharmacology 26, 94-95.

14. Wiles, R. of the Environmental Working Group, quoted in "Atrazine research on non-cancer effects may set precedent for other chemical tests" (K. Werner). Bureau of National Affairs - Daily Environment Report 243, 12.18.00, p. A-8.

15. Keystone Centre (1996). Convening Report Regarding the Formation of the Endocrine Disrupter Screening and Testing Advisory Committee. Web site http://www.epa.gov/oscpmont/oscpendo/history/ keystone.htm. Washington, DC, USA: US Environmental Protection Agency (Accessed 18.01.00).

16. Endocrine Disrupter Screening and Testing Advisory Committee (EDSTAC) (1998). Final Report (Vols 1 and 2). Web site http://www.epa.gov/scipoly/oscpendo/history/ finalrpt.htm. Washington, DC, USA: US Environmental Protection Agency (Accessed 08.05.02).

17. Timm, G. (2002). Criteria for Screens - Review of the EDSTAC Recommendations. Presentation to the US EPA Endocrine Disrupter Methods Validation Subcommittee, 23 July 2002, 5pp. Washington, DC, USA: US Environmental Protection Agency.

18. OECD (2002). Endocrine Disrupters Testing and Assessment Issues, 6pp. Paris, France: OECD.

19. Fail, P.A., Sloan, C.S., Johnson, J.D. \& Brown, V.J. (2002). Draft Detailed Review Paper on Steroidogenesis Screening Assays and Endocrine Disrupters, 217pp. Washington, DC, USA: US Environmental Protection Agency.

20. US EPA (2002). Endocrine Disrupter Screening Programme - Screening Technology Challenge Programme - Request for Information. Web site http:// www.epa.gov/oscpmont/oscpendo/edtechchallenge5. htm. Washington, DC, USA: US Environmental Protection Agency (Accessed 05.01.02).

21. US EPA (2001). Assays and Phases for EDMVS' Advice and Recommendations. Presentation to the US EPA Endocrine Disrupter Methods Validation Subcommittee, 10-12 December 2001, 2pp. Washington, DC, USA: US Environmental Protection Agency.

22. US EPA (2002). Endocrine Disrupter Screening Programme Overview. Web site http://www. epa.gov/ scipoly/oscpendo/overview.htm. Washington,
DC, USA: US Environmental Protection Agency (Accessed 08.12.02).

23. US EPA (2002). The EDMVS Draft Work Plan. Presentation to the US EPA Endocrine Disrupter Methods Validation Subcommittee, 25 March 2002, 4pp. Washington, DC, USA: US Environmental Protection Agency.

24. Joint Subcommittee of the US EPA Science Advisory Board and Scientific Advisory Panel (1999). Review of the EPA's Proposed Environmental Endocrine Disrupter Screening Programme, 46pp. Washington, DC, USA: US Environmental Protection Agency.

25. Baker, F.W. (1998). Comments of the Proctor and Gamble Company to the Science Advisory Panel and the Science Advisory Board on the Report of the Endocrine Disrupter Screening and Testing Advisory Committee, 2pp. Cincinnati, OH, USA: P\&G.

26. Byrd, D.M. III (1999). Comments of Consultants in Toxicology, Risk Assessment and Product Safety to the US EPA about a Proposed Endocrine Disrupter Screening Programme, 4pp. Washington, DC, USA: CTRAPS.

27. Kanno, J., Onyon, L., Haseman, J., Fenner-Crisp, P., Ashby, J. \& Owens, W. (2001). The OECD program to validate the rat uterotrophic bioassay to screen compounds for in vivo estrogenic responses: phase 1. Environmental Health Perspectives 109, 785-794.

28. OECD Environment Directorate (2001). Detailed Review Paper - Appraisal of Test Methods for Sex Hormone Disrupting Chemicals. OECD Environment Health and Safety Publications Series on Testing and Assessment, No. 21, 320pp. Paris, France: OECD.

29. Smeets, J.M., Rankouhi, T.R., Nichols, K.M., Komen, H., Kaminski, N.E., Geisy, J.P. \& van den Berg, M. (1999). In vitro vitellogenin production by carp (Cyprinus carpio) hepatocytes as a screening method for determining (anti)estrogenic activity of xenobiotics. Toxicology and Applied Pharmacology 157, 68-76.

30. Monteverdi, G.H. \& Di Giulio, R.T. (1999). An enzyme-linked immunosorbent assay for estrogenicity using primary hepatocyte cultures from the channel catfish (Ictalurus punctatus). Archives of Environmental Contamination and Toxicology 37, 62-69.

31. Absorption Systems LP. Undated. Validation of the Caco-2 Epithelial Cell Culture System for Permeability Evaluation According to the Biopharmaceutics Classification System. Web site http://www. absorption.com/services/bcs/index.asp. Exton, PA, USA: Absorption Systems (Accessed 30.10.02).

32. Fayet, G. \& Hovsepian, S. (2002). Isolation of a normal human thyroid cell line: hormonal requirement for thyroglobulin regulation. Thyroid 12, 539-546.

33. Bidey, S.P., Chiovato, L., Day, A., Turmaine, M., Gould, R.P., Ekins, R.P. \& Marshall, N.J. (1984). Evaluation of the rat thyroid cell strain FRTL-5 as an in vitro bioassay for thyrotrophin. Journal of Endocrinology 101, 269-276.

34. Hovsepian, S. \& Fayet, G. (1993). In vitro reorganisation of porcine thyroid cells from the ATHOS line into follicle-like structures. Cellular and Molecular Biology (Noisy-le-grand) 39, 427-433. 